\title{
sciendo
}

\section{FISH BIODIVERSITY, THREAT STATUS AND CONSERVATION SIGNIFICANCE OF THE JAMUNA RIVER, BANGLADESH}

\author{
Sulav Indra Paul ${ }^{1+}$, Bhaskar Chandra Majumdar ${ }^{2 *+}$, Mahmudul Hasan $^{3}$, Apurbo Kumer Sarker ${ }^{4}$, Arpan \\ Baidya ${ }^{5}$, Md. Azizul Hakim ${ }^{6}$ \\ ${ }^{1}$ Institute of Biotechnology and Genetic Engineering, Bangabandhu Sheikh Mujibur Rahman Agricultural Uni- \\ versity, Gazipur-1706, Bangladesh \\ 2 Department of Fisheries Technology, Bangabandhu Sheikh Mujibur Rahman Agricultural University, Gazi- \\ pur- 1706, Bangladesh \\ ${ }^{3}$ Department of Marine Science, University of Gothenburg, Gothenburg, Sweden \\ ${ }^{4}$ Faculty of Fisheries, Bangabandhu Sheikh Mujibur Rahman Agricultural University, Gazipur- 1706, Bangla- \\ desh \\ ${ }^{5}$ Department of Aquaculture, Bangabandhu Sheikh Mujibur Rahman Agricultural University, Gazipur- 1706, \\ Bangladesh \\ ${ }^{6}$ Department of Agricultural Extension and Rural Development, Bangabandhu Sheikh Mujibur Rahman Agri- \\ cultural University, Gazipur-1706, Bangladesh \\ ${ }^{+}$These authors contributed equally to this work. \\ *Corresponding Author: bhaskar.bsmrau@gmail.com
}

\section{ARTICLE INFO}

Received: 18 May 2020

Accepted: 22 February 2021

\begin{abstract}
The present survey aimed to explore the fish fauna diversity, abundance and conservation status in the Jamuna River, a tributary of the River Brahmaputra, Bangladesh. During the study period from November 2018 to October 2019, a total of 55 species of fish were recorded, belonging to 6 orders, 20 families and 41 genera from the five selected stations near the river. Orders Cypriniformes and Siluriformes were recorded as the dominant group in the fish fauna community that comprises $34.55 \%$ and $30.91 \%$ of total species, respectively. Various types of Small Indigenous Species (SIS) and a total of 26 International Union for Conservation of Nature (IUCN) red-listed species were recorded. Population indices, viz. Shannon-Weaver index (H), Simpson's dominance index (D), Simpson's index of diversity (1-D), Margalef's index (d) and Evenness (E), were applied to demonstrate the species diversity, richness and evenness of fish, and their overall values were $1.28-1.48,0.26-0.33,0.67-0.74,1.22$ 1.46 and $0.77-0.86$, respectively. To sustain the prospect of fisheries biodiversity in the Jamuna River of Bangladesh, different fish management and conservation plan of action specifically establishing and maintaining fish sanctuaries, banning indiscriminate fishing and the use of destructive fishing gears for the protection of the breeding and nursery grounds of fish should be taken into consideration with utmost priority.
\end{abstract}

Paul, S. I., Majumdar, B. C., Hasan, M., Sarker, A. K., Baidya, A., Hakim, M. A. (2021): Fish biodiversity, threat status and conservation significance of the Jamuna River, Bangladesh. Croatian Journal of Fisheries, 79, 173-186. DOI: 10.2478/cjf-2021-0019. 


\section{INTRODUCTION}

Bangladesh is a riverine country having many rivers, canals, floodplains, ponds, beels, haors, reservoirs, manmade lakes and an extended coastline (Hemal et al., 2017). A network of rivers such as the Padma, the Meghna, the Jamuna, the Teesta, the Brahmaputra, the Surma and the Karnafully are the most important, and the tributaries, numbering about 230 with a complete length of about $24,140 \mathrm{~km}$, criss-cross the country and eventually flow down the Bay of Bengal (BBS, 1991). The Jamuna River plays an important role in the fisheries of Bangladesh. A huge amount of fish are caught from this river annually. The river is important and familiar in northwest Bangladesh in terms of fish production and source of income for many fishermen living beside the river. There are about 260 species of freshwater fish available in the freshwater of Bangladesh (Rahman, 1989; Majumdar, 2017). Fish alone contribute around $63 \%$ of animal protein, and various essential vitamin and mineral requirements in the diet of Bangladeshi people (Majumdar et al., 2016; Majumdar and Rashid, 2017; Shovon et al., 2017). Bangladesh is one of the leading fish producing countries in the world (Sheikh et al., 2018). However, at present, the reduction of the abundance of fish species from the inland water bodies of Bangladesh is a burning issue (Galib et al., 2009; Imteazzaman and Galib, 2013).

Throughout the last century, riverine ecosystems have suffered from intense human intervention resulting in habitat loss and degradation and, as a consequence, many fish species have become highly endangered, primarily in rivers where heavy demand is placed on freshwaters (Rahman et al., 2012). However, a total of 54 species in Bangladesh have been proclaimed as threatened by the International Union for Conservation of Nature (IUCN, 2015). Due to overuse expanded by different environmental changes and corruption of the normal living space, a large portion of the wild fish populations has critically declined in the streams and rivers of Bangladesh (Hossain et al., 2012a). All of these findings demonstrate the necessity of particularly detailed biodiversity studies of the river to evaluate the present status and reasonable administration of the waterbody (Shahjahan et al., 2001; Saha and Hossain, 2002; Ahmed et al., 2004; Zafar et al., 2007; Hossain et al., 2009; Hossain et al., 2012a; Hossain et al., 2012b; Rahman et al., 2012; Imteazzaman and Galib, 2013).

No biodiversity lists concerning fish fauna were managed inside the Jamuna River, Sirajganj district of Bangladesh. Furthermore, to oversee the commercially important fish species of the Jamuna River, it is important to find out the threats. For this reason, the present study aimed to assess the present status of the fish species availability and to supply recommendations for economical fisheries management in the Jamuna River, Bangladesh.

\section{MATERIALS AND METHODS}

\section{Study area}

The present investigation was carried out to explore the fish biodiversity status in the Jamuna River, a tributary to the Brahmaputra River (Sirajganj region) of Bangladesh. Regarding sediment and water discharge quantity, the Jamuna River is one of the world's largest streams in Bangladesh and positions among the top three rivers - the Padma, the Meghna, the Jamuna (Hossain et al., 2012b). To collect the species diversity data, the study area was divided into five sampling stations: Chauhali (S1), Belkuchi (S2), Kamarkhanda (S3), Sirajganj Sadar (S4), and Kazipur (S5) areas of the river. The locations were situated in the Sirajganj district between $24^{\circ} 13^{\prime}$ and $24^{\circ} 38^{\prime}$ north latitude and between $89^{\circ} 42^{\prime}$ and $89^{\circ} 39^{\prime}$ east longitudes (Fig. 1). Data were collected from these selected stations at the peak season of catching, which is the month of November and January, during the study period. The investigation was conducted between November 2018 and October 2019.

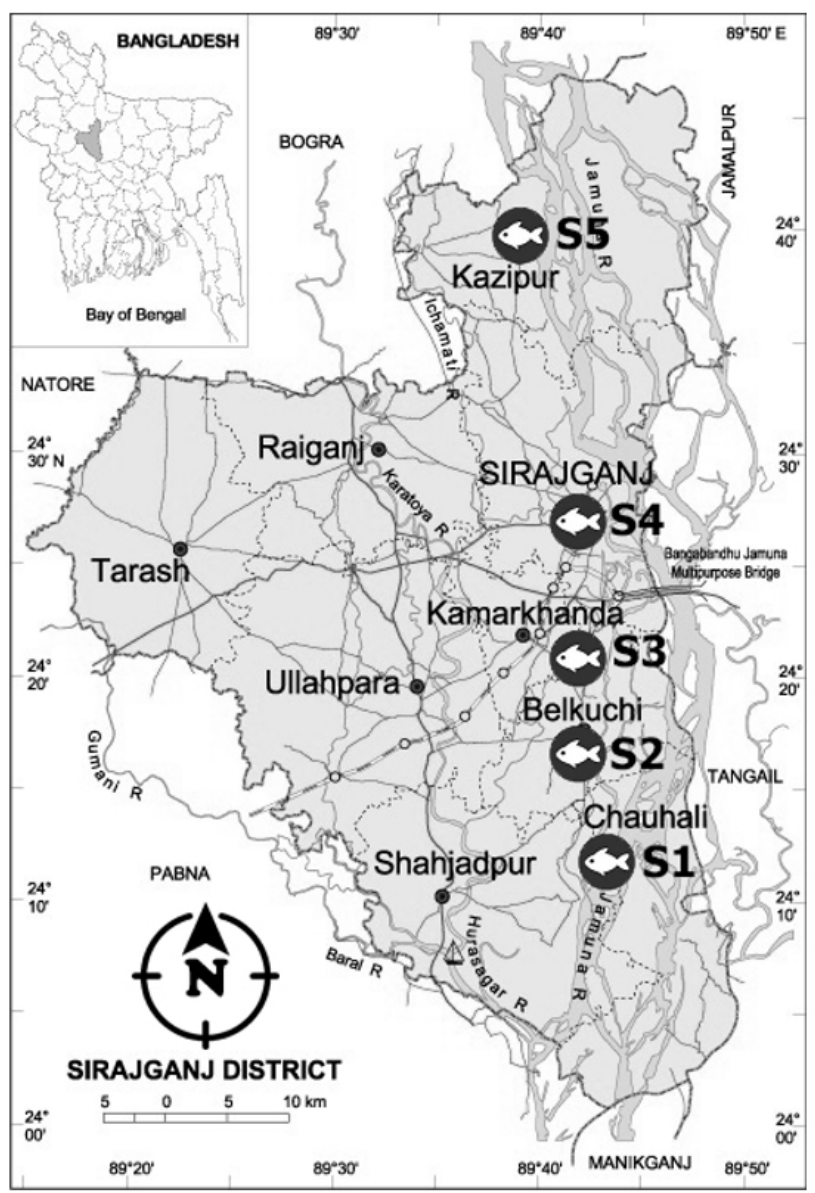

Fig 1. Map showing the study area of the Jamuna River, indicating five sampling sites, S1 (Chauhali; $24^{\circ} 13^{\prime} \mathrm{N}$ $89^{\circ} 42^{\prime} \mathrm{E}$ ), S2 (Belkuchi; $24^{\circ} 18^{\prime} \mathrm{N} 89^{\circ} 41^{\prime} \mathrm{E}$ ), S3 (Kamarkhanda; $\left.24^{\circ} 23^{\prime} \mathrm{N} 89^{\circ} 41^{\prime} \mathrm{E}\right), \mathrm{S} 4$ (Sirajganj Sadar; $24^{\circ} 27^{\prime} \mathrm{N} 89^{\circ} 43^{\prime} \mathrm{E}$ ) and S5 (Kazipur; $24^{\circ} 38^{\prime} \mathrm{N} 89^{\circ} 39^{\prime} \mathrm{E}$ ) of Sirajganj, Bangladesh 


\section{Data collection}

Data were assembled through market visits during the study period and phenotypic traits of fish were carefully observed. Initially, relevant data such as the local name of the collected fish samples, source, distribution and availability of the species were accumulated from the stations. The photograph of the fish was taken on the spot, and consequently species were identified by evaluating their morphometric and meristic characteristics followed by Talwar and Jhingran (1991).

Meanwhile, by observing the fish species at the study area and after discussion with the local fishermen, fish availability status of the Jamuna River was recorded in a notebook according to IUCN (2015) fish availability categories. IUCN (2015) divides species into nine categories and our recorded species were tabulated by cross-checking of predetermination availability categories. Moreover, during fishing practices, commercially interesting species were captured. The main gear used by commercial fishers includes the traditional jhaki jal (cast net), dharma jal (square lift net), tar jal (square lift net), dughair (conical trap) and borsi (fish angles).

\section{Statistical analyses}

Collected data and information were accumulated for analyzing the biodiversity status of the selected stations in the Jamuna River. To illustrate the status as well as species diversity, data were analyzed by using different indices in Microsoft Excel 2016 and finally presented through textual, tabular and graphical format for better understanding.

The Shannon-Weaver diversity index $(\mathrm{H})$ is an insensitive measure $\mathrm{S}$ : $\mathrm{N}$ (proportion of complete pattern represented by species and complete quantity of all individuals of species) and is ruled by the considerable species. The diversity index was determined by the Shannon and Weaver index (1963).

Shannon-Weaver diversity index, $\mathrm{H}=-\Sigma[(\mathrm{Pi}) \times \ln (\mathrm{Pi})]$ where $\mathrm{Pi}=(\mathrm{S}) / \mathrm{N}$

$\mathrm{S}=$ complete pattern represented by species

$\mathrm{N}=$ complete quantity of all individuals.

Evenness is a proportion of the overall abundance of various species, making up the richness of a region, which is estimated using the following equation (Pielou, 1966):

$$
\mathrm{E}=e^{H} / S
$$

Simpson's dominance index (D) is frequently used to evaluate the biodiversity of living space which considers the quantity of species, just as the plenitude of every species and Simpson's index of diversity (1-D) is a proportion of diversity which considers the quantity of species present and the overall abundance of every species, which were measured by using the following equation:

where

$$
\begin{aligned}
D & =\sum[\mathrm{ni}(\mathrm{ni}-1)] /[\mathrm{N}(\mathrm{N}-1)] \\
1-\mathrm{D} & =1-\sum[\mathrm{ni}(\mathrm{ni}-1)] /[\mathrm{N}(\mathrm{N}-1)]
\end{aligned}
$$

(C) 2021 Author(s). This is an open access article licensed under the Creative Commons Attribution-NonCommercial-NoDerivs License

(http://creativecommons.org/licenses/by-nc-nd/3.0/) $\mathrm{ni}=$ complete number of individuals of a specific species $\mathrm{N}=$ overall quantity of individuals of all species.

Margalef's index (d) was utilized to quantify species richness by the following formula (Margalef, 1968):

where

$$
d=(S-1) / \ln (N)
$$

$\mathrm{S}=$ number of species

$\mathrm{N}=$ number of individuals in the sample.

\section{RESULTS}

The river is a refuge for a massive number of aquatic creatures, fish specifically. The current investigation of the fish diversity of the Jamuna River of the Sirajganj district of Bangladesh recorded a total of 55 fish species belonging to 6 orders, 20 families and 41 genera. Order, families, species, English name and local name of fish species recorded during the study period are presented in Table 1. Fish fauna biodiversity, conservation status and distribution of species enlisted through criteria such as rate of decline, population size, area of geographic distribution, and degree of population and distribution fragmentation during data collection in the selected study area are mentioned in Table 2. Meanwhile, the number and percent composition of families, genera and species of fish under various orders are presented in Fig. 2. Specifically, the dominant order was Cypriniformes that comprised $34.55 \%$ of all species recorded in the examination territory.

In the meantime, the Siluriformes (30.91\%) were found as the second most dominant order, whereas the Perciformes $(21.82 \%)$ demonstrated moderate dominancy among the orders. On the contrary, the Synbranchiformes, Osteoglossiformes and Clupeiformes showed the least dominancy and established $7.27 \%$, $3.64 \%$ and $1.82 \%$ in the community, respectively (Fig. 2). The family Cyprinidae under the order Cypriniformes indicated dominancy over the fish fauna network of the Jamuna River by comprising 17 species during the data assortment period (Fig. 2), which was about $30.91 \%$ of the complete variety of species caught from the river.

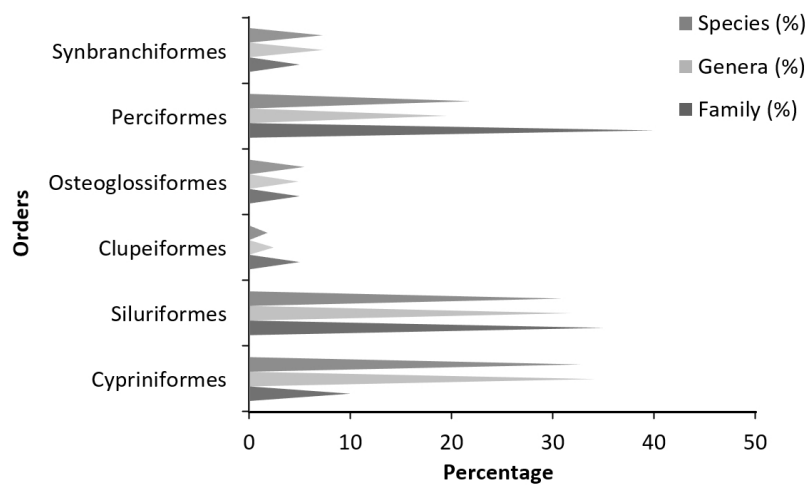

Fig 2. Percentage composition of families, genera and species found under various orders of the fish species in the Jamuna River during the study period 
Table 1. Order, family, scientific, english and local name of fish fauna from the Jamuna River during the study period

\begin{tabular}{|c|c|c|c|c|}
\hline Order & Family & Scientific name & English name & Local name \\
\hline \multirow[t]{19}{*}{ Cypriniformes } & Cobitidae & Botia dario (Hamilton 1822) & Bengal loach & Bou \\
\hline & & Lepidocephalichthys guntea (Hamilton 1822) & Gumtea loach & Gutum \\
\hline & Cyprinidae & Amblypharyngodon mola (Hamilton 1822) & Mola carplet & Mola \\
\hline & & Aspedoparia morar (Hamilton 1822) & Carplet & Murari \\
\hline & & Barbonymus gonionotus (Bleeker 1850) & Java barb & Rajputi \\
\hline & & Cirrhinus cirrhosis (Bloch 1795) & Mrigal & Mrigal \\
\hline & & Ctanophryngodon idella (Valenciennes 1844) & Grass carp & Grass carp \\
\hline & & Cyprinus carpio (Linnaeus 1758) & Common carp & Common carp \\
\hline & & Esomus danricus (Hamilton 1822) & Flying barb & Darkina \\
\hline & & Gibelion catla (Hamilton 1822) & Catla & Katol \\
\hline & & Hypophthalmichthys molitrix (Valenciennes 1844) & Silver carp & Silver carp \\
\hline & & Hypophthalmichthys nobilis (Richardson 1845) & Bighead carp & Bighead carp \\
\hline & & Labeo ariza (Hamilton 1807) & Reba & Bhagna \\
\hline & & Labeo bata (Hamilton 1822) & Bata labeo & Bata \\
\hline & & Labeo calbasu (Hamilton 1822) & Orange fin labeo & Kalibaus \\
\hline & & Labeo gonius (Hamilton 1822) & Kuria labeo & Gonia \\
\hline & & Labeo rohita (Hamilton 1822) & Ruhu carp & Ruhu \\
\hline & & Pethia ticto (Hamilton 1822) & Ticto barb & Tit punti \\
\hline & & Puntius terio (Hamilton 1822) & Onespot barb & Teriputi \\
\hline \multirow[t]{13}{*}{ Siluriformes } & Bagridae & Rita rita (Hamilton 1822) & Rita & Rita maach \\
\hline & & Mystus vittatus (Bloch 1794) & Striped river catfish & Tengra \\
\hline & & Mystus tengra (Hamilton 1822) & Tengra mystus & Gulsha tengra \\
\hline & & Mystus cavasius (Hamilton 1822) & Gangetic tengra & Gang tenga \\
\hline & & Sperata aor (Hamilton 1822) & Long-whiskered catfish & Aor \\
\hline & & Sperata seenghala (Sykes 1839) & Giant river-catfish & Guizza aor \\
\hline & Clariidae & Clarias batrachus (Linnaeus 1758) & Air breathing catfish & Magur \\
\hline & Heteropneustidae & Heteropneustes fossilis (Bloch 1794) & Stringing catfish & Shing \\
\hline & Loricarridae & Hypostomus plecostomus (Linnaeus 1758) & Sucker mouth catfish & $\begin{array}{l}\text { Sucker mouth } \\
\text { catfish }\end{array}$ \\
\hline & Pangasiidae & Pangasius pangasius (Valenciennes 1840) & Yellow tail catfish & Pangas \\
\hline & Schilbeidae & Ailia coila (Hamilton 1822) & Jamuna aila & Baspata \\
\hline & & Clupisoma garua (Hamilton 1822) & Garua bachua & Garua \\
\hline & & Silonia silondia (Hamilton 1822) & Schilbid catfish & Shillong \\
\hline
\end{tabular}


Continued.

\begin{tabular}{|c|c|c|c|c|}
\hline Order & Family & Scientific name & English name & Local name \\
\hline & Siluridae & Wallogo attu (Bloch \& Schneider 1801) & Freshwater shark & Boal \\
\hline & & Ompok bimaculatus (Bloch 1794) & Pabo catfish & Kani Pabda \\
\hline & & Ompok pabda (Lacpede 1803) & Pabda catfish & Pabda \\
\hline & & Bagarius bagarius (Hamilton 1822) & Dwarf goonch & Baghair \\
\hline Clupeiformes & Clupeidae & Gonialosa manmina (Hamilton 1822) & Ganges River Gizzard Sha & Chapila \\
\hline \multirow[t]{2}{*}{ Osteoglossiformes } & Notoptetidae & Chitala chitala (Hamilton 1822) & Humped featherback & Chital \\
\hline & & Notopterus notopterus (Pallas 1769) & Grey featherback & Foly \\
\hline \multirow[t]{12}{*}{ Perciformes } & Ambessdae & Chanda ranga (Hamilton 1822) & Indian glassy fish & Ranga chanda \\
\hline & & Chanda nama (Hamilton 1822) & Elongate glass perchlet & Nama chanda \\
\hline & Anabantidae & Anabus testudineus (Bloch 1792) & Climbing perch & Koi \\
\hline & Belontiidae & Trichogaster fasciata (Bloch \& Schneider 1801) & Striped gourami & Kholisha \\
\hline & Channidae & Channa marulius (Hamilton 1822) & Great snakehead & Gozar \\
\hline & & Channa striata (Bloch 1793) & Snakehead murrel & Shol \\
\hline & & Channa orientalis (Bloch \& Schneider 1801) & Walking snakehead & Gachua \\
\hline & & Channa punctata (Bloch 1793) & Spotted snakehead & Taki \\
\hline & Cichlidae & Oreochromis niloticus (Linnaeus 1758) & Nile tilapia & Tilapia \\
\hline & Gobiidae & Glossogobius giuris (Hamilton 1822) & Tank goby & Bele \\
\hline & Nandidae & Nandus nandus (Hamilton 1822) & Gangetic leaffish & Meni \\
\hline & Osphronemidae & Trichogaster fasciata (Bloch \& Schneider 1801) & Banded gourami & Kholisha \\
\hline \multirow[t]{4}{*}{ Synbranchiformes } & Mastacembelidae & Macrognathus aculeatus (Bloch 1786) & Striped spiny eel & Tara baim \\
\hline & & Macrognathus aral (Bloch \& Schneider 1801) & One striped spiny eel & Guchi baim \\
\hline & & Mastacembelus armatus (Lacepede 1800) & Tire track eel & Baim \\
\hline & & Monopterus cuchia (Hamilton 1822) & Cuchia & Kuchia \\
\hline
\end{tabular}


Table 2. Fish fauna biodiversity, conservation status and presence of species in the selected study area

\begin{tabular}{|c|c|c|c|c|c|c|c|c|}
\hline \multirow{2}{*}{ Order } & \multirow{2}{*}{ Scientific name } & \multirow{2}{*}{ Availability } & \multirow{2}{*}{ Status } & \multicolumn{5}{|c|}{ Study area (Stations) } \\
\hline & & & & S1 & S2 & S3 & S4 & S5 \\
\hline \multirow[t]{19}{*}{ Cypriniformes } & Botia dario (Hamilton 1822) & VR & EN & & & $\checkmark$ & & \\
\hline & Lepidocephalichthys guntea (Hamilton 1822) & VR & LC & & & $\checkmark$ & & \\
\hline & Amblypharyngodon mola (Hamilton 1822) & TYS & LC & $\checkmark$ & & $\checkmark$ & $\checkmark$ & \\
\hline & Aspedoparia morar (Hamilton 1822) & TYS & VU & & $\checkmark$ & & & $\checkmark$ \\
\hline & Barbonymus gonionotus (Bleeker 1850) & $\mathrm{R}$ & LC & & & $\checkmark$ & & $\checkmark$ \\
\hline & Cirrhinus cirrhosis (Bloch 1795) & VR & NT & & $\checkmark$ & & & \\
\hline & Ctanophryngodon idella (Valenciennes 1844) & TYL & NE & & $\checkmark$ & $\checkmark$ & $\checkmark$ & \\
\hline & Cyprinus carpio (Linnaeus 1758) & TYS & VU & $\checkmark$ & & $\checkmark$ & $\checkmark$ & \\
\hline & Esomus danricus (Hamilton 1822) & TYL & LC & $\checkmark$ & & & $\checkmark$ & $\checkmark$ \\
\hline & Gibelion catla (Hamilton 1822) & TYS & LC & & $\checkmark$ & & & $\checkmark$ \\
\hline & Hypophthalmichthys molitrix (Valenciennes 1844) & TYL & NT & $\checkmark$ & $\checkmark$ & $\checkmark$ & $\checkmark$ & $\checkmark$ \\
\hline & Hypophthalmichthys nobilis (Richardson 1845) & TYL & DD & $\checkmark$ & $\checkmark$ & $\checkmark$ & $\checkmark$ & \\
\hline & Labeo ariza (Hamilton 1807) & TYL & VU & $\checkmark$ & $\checkmark$ & $\checkmark$ & $\checkmark$ & \\
\hline & Labeo bata (Hamilton 1822) & TYL & LC & $\checkmark$ & $\checkmark$ & $\checkmark$ & $\checkmark$ & $\checkmark$ \\
\hline & Labeo calbasu (Hamilton 1822) & $\mathrm{R}$ & LC & & & $\checkmark$ & & \\
\hline & Labeo gonius (Hamilton 1822) & TYS & NT & & & & $\checkmark$ & $\checkmark$ \\
\hline & Labeo rohita (Hamilton 1822) & TYL & LC & & & & $\checkmark$ & \\
\hline & Pethia ticto (Hamilton 1822) & TYS & LC & & $\checkmark$ & $\checkmark$ & $\checkmark$ & $\checkmark$ \\
\hline & Puntius terio (Hamilton 1822) & TYS & LC & & $\checkmark$ & $\checkmark$ & $\checkmark$ & $\checkmark$ \\
\hline \multirow[t]{12}{*}{ Siluriformes } & Rita rita (Hamilton 1822) & $\mathrm{R}$ & EN & & & $\checkmark$ & & \\
\hline & Mystus vittatus (Bloch 1794) & TYL & LC & $\checkmark$ & $\checkmark$ & $\checkmark$ & $\checkmark$ & $\checkmark$ \\
\hline & Mystus tengra (Hamilton 1822) & TYL & LC & $\checkmark$ & $\checkmark$ & $\checkmark$ & $\checkmark$ & $\checkmark$ \\
\hline & Mystus cavasius (Hamilton 1822) & TYS & LC & $\checkmark$ & $\checkmark$ & $\checkmark$ & & \\
\hline & Sperata aor (Hamilton 1822) & TYS & VU & & $\checkmark$ & & & $\checkmark$ \\
\hline & Sperata seenghala (Sykes 1839) & $\mathrm{R}$ & VU & & $\checkmark$ & & & \\
\hline & Clarias batrachus (Linnaeus 1758) & TYS & LC & $\checkmark$ & & & $\checkmark$ & \\
\hline & Heteropneustes fossilis (Bloch 1794) & TYS & LC & & $\checkmark$ & $\checkmark$ & & \\
\hline & Hypostomus plecostomus (Linnaeus 1758) & TYS & NA & $\checkmark$ & & & $\checkmark$ & $\checkmark$ \\
\hline & Pangasius pangasius (Valenciennes 1840) & VR & EN & & & & & $\checkmark$ \\
\hline & Ailia coila (Hamilton 1822) & $\mathrm{R}$ & NT & & $\checkmark$ & $\checkmark$ & & \\
\hline & Clupisoma garua (Hamilton 1822) & VR & LC & $\checkmark$ & & & $\checkmark$ & \\
\hline
\end{tabular}


Continued.

\begin{tabular}{|c|c|c|c|c|c|c|c|c|}
\hline \multirow{2}{*}{ Order } & \multirow{2}{*}{ Scientific name } & \multirow{2}{*}{ Availability } & \multirow{2}{*}{ Status } & \multicolumn{5}{|c|}{ Study area (Stations) } \\
\hline & & & & S1 & S2 & S3 & S4 & S5 \\
\hline & Silonia silondia (Hamilton 1822) & TYS & LC & & $\checkmark$ & & & $\checkmark$ \\
\hline & Wallogo attu (Bloch \& Schneider 1801) & TYL & VU & $\checkmark$ & & $\checkmark$ & $\checkmark$ & $\checkmark$ \\
\hline & Ompok bimaculatus (Bloch 1794) & TYS & NT & & $\checkmark$ & $\checkmark$ & & \\
\hline & Ompok pabda (Lacpede 1803) & TYS & NT & $\checkmark$ & & $\checkmark$ & & $\checkmark$ \\
\hline & Bagarius bagarius (Hamilton 1822) & VR & NT & & & & $\checkmark$ & \\
\hline Clupeiformes & Gonialosa manmina (Hamilton 1822) & TYL & $\mathrm{LC}$ & $\checkmark$ & $\checkmark$ & $\checkmark$ & $\checkmark$ & \\
\hline \multirow[t]{2}{*}{ Osteoglossiformes } & Chitala chitala (Hamilton 1822) & $\mathrm{R}$ & NT & & $\checkmark$ & & & $\checkmark$ \\
\hline & Notopterus notopterus (Pallas 1769) & $\mathrm{R}$ & VU & & & $\checkmark$ & & \\
\hline \multirow[t]{12}{*}{ Perciformes } & Chanda ranga (Hamilton 1822) & TYL & $\mathrm{LC}$ & $\checkmark$ & $\checkmark$ & $\checkmark$ & $\checkmark$ & $\checkmark$ \\
\hline & Chanda nama (Hamilton 1822) & TYL & LC & $\checkmark$ & $\checkmark$ & $\checkmark$ & $\checkmark$ & $\checkmark$ \\
\hline & Anabus testudineus (Bloch 1792) & TYS & LC & $\checkmark$ & $\checkmark$ & $\checkmark$ & & $\checkmark$ \\
\hline & Trichogaster fasciata (Bloch \& Schneider 1801) & TYS & LC & & $\checkmark$ & $\checkmark$ & $\checkmark$ & \\
\hline & Channa marulius (Hamilton 1822) & $\mathrm{R}$ & EN & $\checkmark$ & & $\checkmark$ & & \\
\hline & Channa striata (Bloch 1793) & TYL & LC & & $\checkmark$ & $\checkmark$ & $\checkmark$ & \\
\hline & Channa orientalis (Bloch \& Schneider 1801) & TYS & VU & $\checkmark$ & & & & \\
\hline & Channa punctata (Bloch 1793) & TYL & $\mathrm{LC}$ & $\checkmark$ & $\checkmark$ & & & $\checkmark$ \\
\hline & Oreochromis niloticus (Linnaeus 1758) & TYL & LC & $\checkmark$ & $\checkmark$ & $\checkmark$ & $\checkmark$ & $\checkmark$ \\
\hline & Glossogobius giuris (Hamilton 1822) & VR & LC & & & $\checkmark$ & & \\
\hline & Nandus nandus (Hamilton 1822) & VR & NT & & & $\checkmark$ & & \\
\hline & Colisa fasciata (Bloch \& Schneider 1801) & TYS & LC & & $\checkmark$ & $\checkmark$ & & $\checkmark$ \\
\hline \multirow[t]{4}{*}{ Synbranchiformes } & Macrognathus aculeatus (Bloch 1786) & TYS & LC & & $\checkmark$ & & $\checkmark$ & \\
\hline & Macrognathus aral (Bloch \& Schneider 1801) & TYS & LC & & & $\checkmark$ & & $\checkmark$ \\
\hline & Mastacembelus armatus (Lacepede 1800) & TYS & LC & $\checkmark$ & $\checkmark$ & & & \\
\hline & Monopterus cuchia (Hamilton 1822) & VR & VU & & & & & $\checkmark$ \\
\hline
\end{tabular}

Note: TYS = Throughout the year in small amount; TYL = Throughout the year in large amount; $R=$ Rare; VR = Very rare; $L C=L$ Least concern; EN = endangered; VU = vulnerable; NT = Near threatened; NE = Not evaluated; NA = Not available; DD = Data deficient; $\mathrm{S} 1=\mathrm{Chauhali}$ station, $\mathrm{S} 2$ = Belkuchi station; S3 = Kamarkhanda station; S4 = Sirajganj sadar station and S4 = Kazipur station 
The least dominant families of that community were the Clariidae, Heteropneustidae, Loricarridae, Pangasiidae, Clupeidae, Anabantidae, Belontiidae, Cichlidae, Gobiidae, Nandidae and Osphronemidae that contributed only one species in that network during the investigation time frame.

\section{Present status of fish}

Among 55 species, 16 species were normally found throughout the year in large amounts, while 22 species were also found throughout the year but in limited quantity. Moreover, in view of the species availability, 9 of them were found very rarely and 8 species were enlisted as rare in the community (Fig. 3).

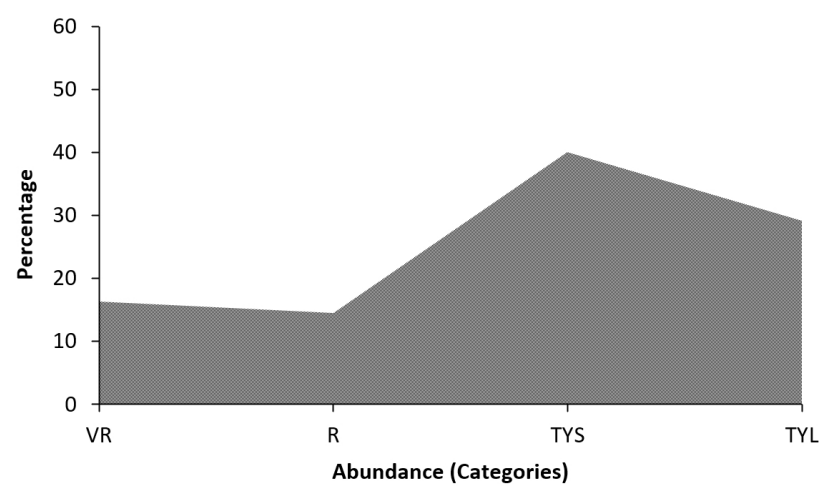

Fig 3. Abundance status of the versatile group of species found in the Jamuna River (VR: very rare, R: rare, TYS: found throughout the year in a small amount, TYL: found throughout the year in a large amount)

The percentage of fish abundance based on their availability status indicated that $29.09 \%$ of fish species were found in large amounts throughout the year, as well as $40 \%$ of species were in small quantities throughout the year in the Jamuna River. In the meantime, $14.55 \%$ of species of fish were rarely found in the river, whereas $16.36 \%$ of species were very rare in the fish community of the river.

Out of the 55 fish species, a maximum number (35) of threatened species was recorded at Kamarkhanda (S3), followed by Belkuchi (S2), Kazipur (S5), Sirajganj sadar (S4) and Chauhali (S1) areas where 31, 27, 26 and 24 threatened fish species were found, respectively. At that time, the highest number of individuals $(8,572)$ was recorded at Kamarkhanda (S3), followed by Belkuchi (S2), Chauhali (S1), Sirajganj sadar (S4) and Kazipur (S5) areas, where $8,159,7,489,7,336$ and 7,238 individuals were recorded, respectively. Compared to all the stations, the highest species richness was recorded at Kamarkhanda (S3) station (Table 3).

\section{Biodiversity of the threatened fish species}

26 IUCN red-listed species were found in the studied areas. The dominant portion was vulnerable (16), followed by endangered (6) and near threatened (4) (Fig. 4). The percentage compositions of the endangered, vulnerable and near-threatened categories were found to be $10.91 \%, 29.09 \%$ and $7.27 \%$, respectively. A total of 30 species, which comprises $54.55 \%$ of the total community, were assessed as Least Concern. Maximum numbers of 4 endangered species were noticed at sampling stations $\mathrm{S} 1$, and 3 at station S3, whereas no species with endangered status were found at station S2. Alarmingly, no species with critically endangered status were noticed during the study period.

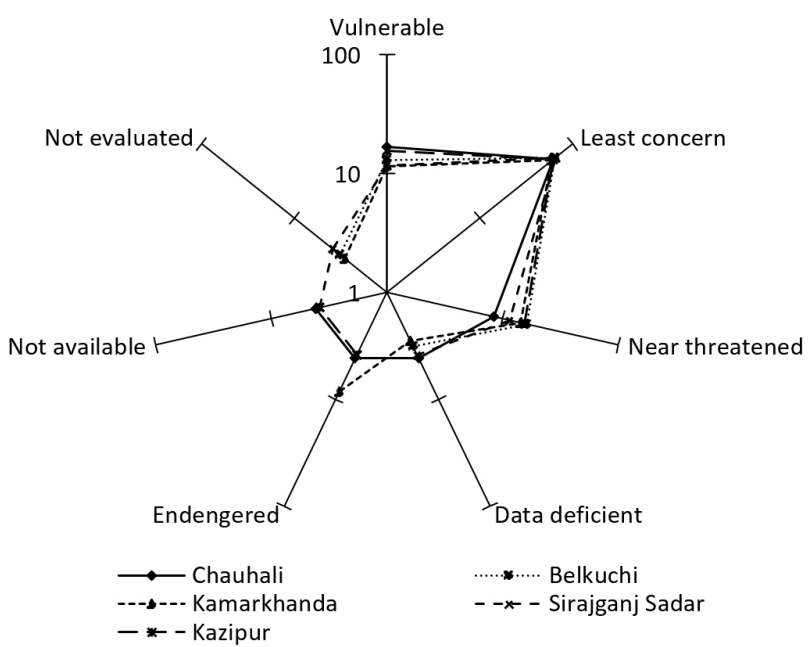

Fig 4. Species under different categories of threat as per IUCN (2015) found in the selected study site of the Jamuna River during the study period

\section{Biodiversity index}

The area-wise value of the Shannon-Weaver index $(H)$, Simpson's dominance index (D), Simpson's index of diversity (1-D) and Margalef's richness index (d) are presented in Fig. 5. From the studied area, the highest Shannon-Weaver index value (1.48) was observed at Belkuchi (S2) station and the lowest value (1.28) was found at Sirajganj sadar (S4) station. The highest value of Simpson's dominance index (0.33) was estimated in the Sirajganj sadar (S4) area, followed by 0.29 in Kamarkhanda (S3) and Chauhali (S1), 0.28 in Kazipur (S5), and the lowest 0.26 at Belkuchi (S2) station.

Table 3. Total number of threatened species and individuals found in the study area

\begin{tabular}{lccccc}
\hline \hline Study area (Stations) & Chauhali (S1) & Belkuchi (S2) & Kamarkhanda (S3) & Sirajganj Sadar (S4) & Kazipur (S5) \\
\hline Total number of threatened species & 24 & 31 & 35 & 26 & 27 \\
Total number of indivi-duals & 7489 & 8159 & 8572 & 7336 & 7238 \\
\hline \hline
\end{tabular}




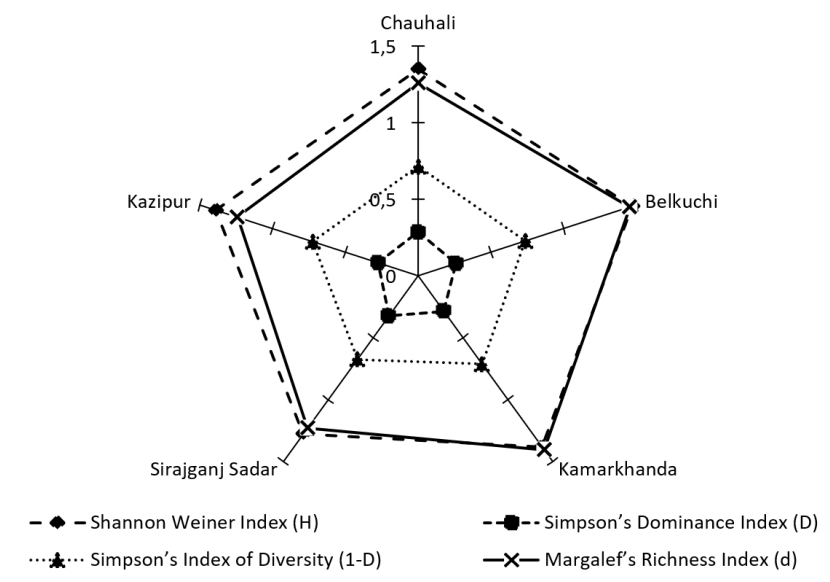

Fig 5. Distinct fish diversity index of sampling sites of the Jamuna River

The highest Simpson's index of diversity (0.74) was recorded in the Belkuchi (S2) area and the lowest (0.67) was recorded in Kazipur (S5) area. The highest Margalef's index value of 1.46 was recorded at Belkuchi (S2) station, whereas the lowest value of 1.22 was noticed at Sirajganj sadar (S4) station (Fig. 5). The highest evenness value of 0.86 was recorded at Kazipur (S5) station and the lowest value of 0.77 was noticed at Kamarkhanda (S3) station (Fig. 6).

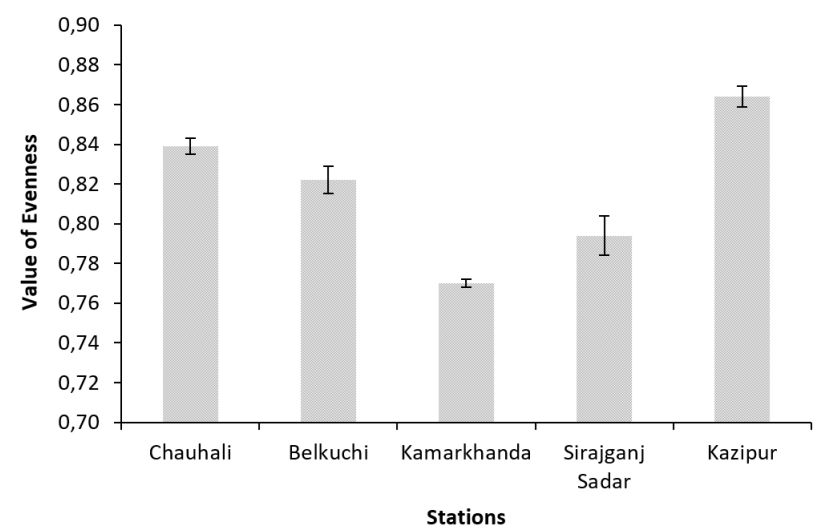

Fig 6. Evenness of fish diversity in distinct sampling sites of the River Jamuna

\section{DISCUSSION}

As the River Jamuna harbors a plentiful amount of fish fauna, the present study revealed 55 fish species from the five sampling stations in the River Jamuna, representing $21.15 \%$ of the country's total fish species (Table 2). Islam et al. (2016) previously studied the fish fauna of the Jamuna River for one year and six months, from August 2014 to February 2016, and they recorded a total of 55 species under 44 genera and 28 families from the Jamuna River. Our study also recorded the same number of species from the river but the main difference is in the species variability. In fact, among all the orders both studies recorded the maximum number of contributions from the Cypriniformes followed by the Siluriformes and Perciformes. The dominance of the fish from these three orders is the most common scenario in the case of freshwater fish in Bangladesh (Rahman et al., 2012; Mohsin et al., 2013; Rahman et al., 2015; Hossain, 2014). In the meantime, compared to Islam et al. (2016), thirteen more species under this order from the River Jamuna were recorded in this study. These were the following: Labeo ariza, L. gonius and L. rohita, Cirrhinus cirrhosis, Lepidocephalichthys guntea, Aspedoparia morar, Ctanophryngodon idella, Esomus danricus, Gibelion catla, Hypophthalmichthys molitrix, H. nobilis, Pethia ticto and Puntius terio. Surprisingly, we recorded the presence of fish from the Loricarridae, Anabantidae and Cichlidae families from the River Jamuna, as well as nine species were added to the list from the rest of the families, such as Mystus cavasius, Hypostomus plecostomus, Silonia silondia, Ompok bimaculatus, Gonialosa manmina, Notopterus notopterus, Anabus testudineus, Trichogaster fasciata and Macroganthus aral. Migration of species may occur due to the variation of various extrinsic factors such as water level, precipitation, current and discharge, photoperiod, lunar cycle, dissolved oxygen concentration, temperature, turbidity and water color, fish density, hunger and presence of certain insects in the environment. Other reasons include more favourable living or breeding conditions, for example, fish moving up or down the river depending on their breeding cycles (Nabi et al., 2014). However, these findings ensured the improvement of the fish biodiversity level of the Jamuna River in the last few years. Specifically, various types of incentive-based administration estimates play a vital role in increasing the plenitude of fish species in the open water system of Bangladesh. That is why fishermen capture various types of fish from the Jamuna River (Suravi et al., 2017; Islam et al., 2016). Although a study on fish passage between the Jamuna and Bangali rivers recorded a total of 69 fish species under 9 orders and 26 families by using different types of fine nets, that is a little bit more than in our study (Zaman and Naser, 2019). Previously, Bhuiyan (1964) concluded a survey on the River Buriganga in Dhaka by recording a total of 71 freshwater fish species under 25 families and 45 genera from the river, but in recent years Baki et al. (2017) reported a total of 56 fish species belonging to 20 families and 9 orders from the same river. The water quality of the river has been deteriorating due to intensive human intervention, unplanned urbanization, rapid industrialization and population pressure around the river (Sarker, 2005; Moniruzzaman et al., 2009; Nouri et al., 2009). The large input of organic matter to aquatic flood plain habitats may reduce the amont of dissolved oxygen which results in the emigration or reduction of a great number of fish in the river (Winemiller, 1989; Baki et al., 2017). Threats from these types of human intervention might be a potential reason for species reduction in the River Buriganga. On the other hand, Rahman (2005) enlisted an aggregate of 265 freshwater fish species 
from open water bodies of Bangladesh divided into 154 genera and 55 families. Islam et al. (2017) reported a total of 39 species of fish from the Bhairab River of Jessore, Bangladesh. Recently, Majumdar et al. (2020) reported 51 species of commercially interesting fish under 7 orders and 19 families from the Chinadi beel wetland area of Narsingdi, Bangladesh. So by considering this expanded species richness of various open water bodies in Bangladesh, the Jamuna River is full of moderately diversified fish species.

In this present study, we were able to explore $40 \%$ of the total fish species from the selected study area of the Jamuna River that were in threatened condition (IUCN, 2015). Moreover, $14.55 \%$ of the recorded fish were rarely found throughout the year, whereas $16.36 \%$ in the case of very rarely found species. In this present context, additional management practices and conservation measures throughout the year will help improve the number of threatened species. Due to diversified ecological conditions of the aquatic ecosystem, a wide scope of species level was perceived from the different locations of the study stations of the Jamuna River. To shoot up the highest species biodiversity of the River Jamuna, the maximum implication of conservation practices in the river must be confirmed (Collares-Pereira and Cowx, 2004; Cowx and Portocarrero, 2011).

A total of 34 small indigenous species (SIS) comprising $61.82 \%$ were recorded from all of the study stations. A maximum of them was found all year round in the Jamuna River. Hoq (2006) recorded a total of 121 species of SIS from Chalan Beel, 123 from Tanguar Haor and 145 from the Baraindra Tract area (Chittagong) of Bangladesh. In Bangladesh, SIS are almost available in all of the water bodies but indiscriminate exploitation of brood and young SIS by using different types of destructive fishing gears and methods leads SIS to a high level of risk of extinction. Among all the vulnerable fish species, Aspedoparia morar, Sperata seenghala, Notopterus notopterus, Channa orientalis and Monopterus cuchia with high market demand were recorded at a very low amount during the survey. During this survey, only one individual of Bagarius bagarius was recorded. Divergent anthropogenic activities are synergistically affecting the water quality parameter and profundity of the Jamuna River (Uddin et al., 2014). The further influence exercised by man and his activities on the biotic community, like excessive fishing practices, is gradually reducing the diversity in the Jamuna River where relatively low human interference of some areas of the river increases fish abundance by retaining an optimum environmental condition (Islam et al., 2020).

As Magurran (1988) defined, biodiversity index refers to the characterization of the species diversity of a sample or community by an individual number. That means diversity will be high when all the fish species create an equally abundant population community. For this reason, several biodiversity index assessments were conducted for the analysis of fish diversity by comparing the estimated values within five selected areas of the Jamuna River. However, the Shannon-Weaver fish diversity index $(\mathrm{H})$ of different sites of the Jamuna River ranged from 1.28 to 1.48 (Fig. 5). Specifically, the maximum fish diversity index was higher in sites such as Belkuchi (S2): (1.48) in comparison with Kazipur (S5): (1.39), Kamarkhanda (S3): (1.38), Chauhali (S1): (1.35) and Sirajganj sadar (S4): (1.28). This indicates good correlation with overall species richness across the sites and could be utilized by the biodiversity conservation authorities for prioritization of sites of conservation and habitat restoration of the Jamuna River. For the enormous scope of the European freshwater basin in France, Bergerot et al. (2008) created indices of fish biodiversity protection concern, irregularity index and fish magnitude values for prioritization of sites. Shannon-Weaver index is fundamentally a proportion of vulnerability, and high vulnerability would demonstrate high diversity. The value of $\mathrm{H}$ usually ranges from 1.5 to 3.5 for ecological data and hardly exceeds 4.0 , but due to a lower number of species, the present study shows a significantly lower $\mathrm{H}$ value that is mostly related to our calculated data. Previously, the value of $\mathrm{H}$ in therivers of Bangladesh ranged from 1.017 to 4.65 in the Bakkhali River (Belaluzzaman, 1995), from 3.427 to 3.818 in the Choto Jamuna River (Galib et al., 2013), from 1.06 to 1.51 in the Talma River (Rahman et al., 2015), from 1.45 to 2.13 in the Shiba River (Khanom et al., 2016), which supports the present finding.

Moreover, Simpson's Dominance Index (D) is a proportion of diversity that considers the number of species present and the overall abundance of every species. In this investigation, the highest $D$ value was found in the Sirajganj sadar (S4) area and the lowest in the Belkuchi (S2) area. Simpson's dominance index (D) value usually ranges from 0 to 1 , and the higher the range of values, the smaller the biodiversity represented. So considering the D value, the Belkuchi (S2) area was found to be the most enriched with species diversity and the Sirajganj sadar (S4) site was found to be the least enriched with species diversity. On the contrary, Simpson's index of diversity (1D) depends on Simpson's dominance index (D); whereas the highest and the lowest Simpson's index of diversity (1-D) were recorded in Belkuchi (S2) and Sirajganj sadar (S4), respectively. So the Belkuchi (S2) area has high species diversity. This partial difference may be due to the temporal variation of dominance status among all five sampling areas.

Margalef's richness index (d) is the most commonly used biodiversity index that is widely used in evaluating species diversity. In the present study, Margalef's richness index varied from 1.22 to 1.46 . This value is an indicator of different sampling sites, while it indicates deviation based on the species number (Vyas et al., 2012). However, the maximum Margalef index value represents the maximum number of individuals in the studied area. So the Belkuchi (S2) sampling area with the highest Margalef's richness index indicates the presence of a remarkably higher 
number of individuals than in other study areas (Fig. 5). Evenness (e) value measures the number of individuals of a species and the value ranges from 1 and 0 . During the study, the maximum evenness value was observed in the Kazipur (S5) area, whereas the tiniest value was observed in the Kamarkhanda (S3) area. The maximum evenness value means the population size of that particular area is higher than in the other area (Fig. 6).

Finally, this survey showed the fish fauna diversity and abundance in a different area of the Jamuna River. Based on different biodiversity index outcomes, Belkuchi (S2) sampling station is comparatively rich in fish biodiversity. In view of the current fish biodiversity of the Jamuna River, a maintainable biodiversity protection activity plan should be implemented. Several common threats are liable for diminishing biodiversity, for example, the devastation of reproducing ground, fishing during the spawning period, overexploitation, siltation, attack by exotic species and utilization of non-particular fishing gears. To stop the loss of biodiversity and hold the present stocks, effective administration strategies are exceptionally fundamental. Establishment of the fish sanctuary, dredging, familiarity with using specific fishing gears, suspension of overexploitation is required. Hydrological improvement and biological network, protection of habitat and disposal of all destructive fishing gears are immediately needed to monitor biodiversity (Hossain, 2014; Rahman, 2015; Galib et al., 2018). Several destructive fishing gears have been highly damaging for juvenile fish, which encompass set bag nets (Badha jal, Behundi jal and Pona jal), beach seine nets (Moshari jal, Char Ghera jal and Ber jal) and smallmeshed monofilament net (Current jal). Appropriate administrative activities would be crucial to implement measures to control destructive gears, particularly gears that capture threatened species.

\section{CONCLUSION}

The rivers in Bangladesh are going through a gradual decline of fish fauna biodiversity and thus a tremendous portion of fish diversity becomes threatened because of manmade and natural hazards. Fisheries diversity is diminished day by day. Leading manmade causes may include dam establishment, unselective catching of fry and fingerling, dangerous pesticide runoff, utilization of current net, etc. Various natural disasters such as floods greatly affect the diversity of the Jamuna River due to heavy rainfall. In the monsoon season, a significant portion of cultured fish becomes accessible in the region due to heavy rainfall followed by floods. From a financial point of view, the occupational categories of fishermen are not profitable. Because of the limited quantity of catches, they cannot find the understanding of money lenders and cannot meet their primary needs. Central and local government has less consideration of their livelihood status and the fishery assets in the river. In this way, their future existence remains the same. To maintain the possibility of fisheries biodiversity in the river nearby, administration and conservation techniques, such as building up and maintaining a fish sanctuary, limitation of dangerous fishing gears, limitation of fishing during the spawning period, need to receive due attention.

\section{ACKNOWLEDGEMENT}

We wish to appreciate the efforts of Kishan Shaha, Noman Hossain for their technical assistance during the study. We additionally offer our thanks to the local fishers of the Jamuna River, Bangladesh for helping us to collect data. Extraordinary thanks are stretched out to those anonymous fishers who helped in various capacities for the successful implementation of this study.

\section{BIODIVERZITET, UGROŽENOST I OČUVANJE RIBLIH VRSTA ZNAČAJNIH ZA RIJEKU JAMUNE, BANGLADEŠ}

\section{SAŽETAK}

Ovo istraživanje provedeno je kako bi se istražila raznolikost, brojnost i status zaštite riblje faune u rijeci Jamuna, pritoku rijeke Brahmaputra u Bangladešu. Ukupno je zabilježeno 55 ribljih vrsta koje pripadaju u 6 redova, 20 porodica i 41 rod, a koje su prikupljene s pet odabranih lokacija u blizini rijeke tijekom razdoblja istraživanja od studenog 2018. do listopada 2019. godine. Red Cypriniformes i Siluriformes zabilježeni su kao dominantne skupine u ribljoj fauni, a koje čine $34,55 \%$ i $30,91 \%$ od ukupno uočenih vrsta. Tijekom razdoblja ispitivanja zabilježene su različite vrste manjih autohtonih vrsta (SIS) i ukupno 26 vrsta s crvene liste Međunarodne unije za zaštitu prirode (IUCN). Shannon Weaverov indeks $(H)$, Simpsonov indeks dominacije (D), Simpsonov indeks raznolikosti (1-D), Margalefov indeks (d) i ravnomjernost (E) izračunati su kako bi se pokazala raznolikost vrsta, bogatstvo i ravnomjernost riba. Tijekom ispitivanog razdoblja i vrijednosti tih parametara su se kretale između 1,28-1,48, 0,26-0,33, 0,67-0,74, 1,22-1,46 i $0,77-0,86$. Ovo istraživanje preporučuje akcijski plan gospodarenja i očuvanja ribe, posebno uspostavljajući i održavajući skloništa za ribe, zabranjujući neselektivni ribolov i upotrebu destruktivnih ribolovnih alata radi zaštite rastilišta i mrijestilišta riba kako bi se održala perspektiva biološke raznolikosti ribarstva u rijeci Jamuna.

Ključne riječi: Rijeka Jamuna, biološka raznolikost riba, indeks raznolikosti, IUCN, očuvanje 


\section{REFERENCES}

Ahmed, K. K. U., Hasan, K. R., Ahamed, S. U., Ahmed, T., Mustafa, G. (2004): Ecology of Shakla heel (Brahmanbaria), Bangladesh. Bangladesh Journal of Fisheries Research, 8, 2, 101-111.

Ali, M. Y., Hossain, M. B., Shamsuddin, M. (2012): Microbiological status in a fully export oriented shrimp processing plant. World Applied Sciences Journal, 16, 7, 903-906.

Baki, M. A., Hossain, M. M., Bhouiyan, N., Asaduzzaman, M. (2017). Fish species diversity, fishing gears and crafts from the Buriganga river, Dhaka. Bangladesh Journal of Zoology, 45, 1, 11-26.

BBS (1991): Statistical yearbook of Bangladesh, Dhaka, Bangladesh: Statistics Divisions, Ministry of Planning Government of the People's Republic of Bangladesh. $729 p p$.

Belaluzzaman, A. M. (1995): Ecology of the intertidal macro benthic fauna in Cox's Bazar coastal area, Bangladesh. MSc Thesis, Institute of Marine Sciences, University of Chittagong. 53-55pp.

Bergerot, B., Lasne, E., Vigneron, T., Laffaille, P. (2008): Prioritization of fish communities with a view to conservation and restoration on a large scale European basin, the Loire (France). Biodiversity and Conservation, 17, 9, 2247-2262.

Bhuiyan, A. L. (1964): Fishes of Dacca, Dacca: Asiatic Society of Pakistan. 148pp.

Collares-Pereira, M. J., Cowx, I. G. (2004): The role of catchment scale environmental management in freshwater fish conservation. Fisheries Management and Ecology, 11, 3-4, 303-312.

Cowx, I. G., Portocarrero, A. (2011): Paradigm shifts in fish conservation: moving to the ecosystem services concept. Journal of Fish Biology, 79, 6, 1663-1680.

Galib, S. M., Lucas, M. C., Chaki, N., Fahad, F. H., Mohsin, A. B. M. (2018): Is current floodplain management a cause for concern for fish and bird conservation in Bangladesh's largest wetland? Aquatic Conservation: Marine and Freshwater Ecosystems, 28, 1, 98-114.

Galib, S. M., Naser, S. M. A., Mohsin, A. B. M., Chaki, N., Fahad, M. F. H. (2013): Fish diversity of the River Choto Jamuna, Bangladesh: present status and conservation needs. International Journal of Biodiversity and Conservation, 5, 6, 389-395.

Galib, S. M., Samad, M. A., Mohsin, A. B. M., Flowra, F. A., Alam, M. T. (2009): Present status of fishes in the Chalan Beel-the largest beel (wetland) of Bangladesh. International Journal of Animal and Fisheries Science, 2, 3, 214-218.

Hemal, S., Uddin, M. S., Uddin, M. S., Majumdar, B. C., Rasul, M. G., Alam, M. T. (2017): Present status and problems of fish seed marketing in Sylhet district, Bangladesh. Research in Agriculture Livestock and Fisheries, 4, 1, 45-54.

Hoq, E. (2006): Bangladesher Chhoto Mach, Published by- Graphic Sign: 8 GKMC Shah Road, Chhoto Bazar, Mymensingh-2200. 20 pp.

Hossain, M. (2014): Threatened fishes of the world: Mystus vittatus (Bloch, 1794)(Siluriformes: Bagridae). Croatian Journal of Fisheries, 72, 4, 183-185.

Hossain, M. A. R., Nahiduzzaman, M., Sayeed, M. A., Azim, M. E., Wahab, M. A., Olin, P. G. (2009): The Chalan beel in Bangladesh: Habitat and biodiversity degradation, and implications for future management. Lakes \& Reservoirs: Research and Management, 14, 3-19.

Hossain, M. S., Das, N. G., Sarker, S., Rahaman, M. Z. (2012a): Fish diversity and habitat relationship with environmental variables at Meghna river estuary, Bangladesh. The Egyptian Journal of Aquatic Research, 38, 3, 213-226.

Hossain, M. Y., Rahman, M. M., Fulanda, B., Jewel, M. A. S., Ahamed, F., Ohtomi, J. (2012b): Length-weight and length-length relationships of five threatened fish species from the Jamuna (Brahmaputra River tributary) River, northern Bangladesh. Journal of Applied Ichthyology, 28, 2, 275-277.

Imteazzaman, A. M., Galib, S. M. (2013): Fish fauna of Halti beel, Bangladesh. International Journal of Current Research, 5, 1, 187-190.

Islam, M. A., Asif, A., Samad, M. A., Sarker, B., Ahmed, M., Satter, A., Hossain, A. (2017). A comparative study on fish biodiversity with conservation measures of the Bhairabriver, Jessore, Bangladesh. Asian Journal of Medical and Biological Research, 3, 3, 357-367.

Islam, M. M., Islam, F., Akter, M. S., Kundu, G. K., Barman, A., Khan, M. I., 2020. Transformative Adaptations to Climate Change: Cases from the Jamuna River Fishing Communities of Bangladesh. Journal of Fisheries and Environment, 44, 3, 1-18.

Islam, S. M., Rahman, M. B., Alam, M. R., Mithun, B. D., Bal, A., Azam, M., Ruma, M. (2016). A case study on fishing gears, fish species composition and fisher folk community at Jamuna river of sirajganj sadar fish landing site, Bangladesh. Journal of Aquatic Science, 4, 11-19.

IUCN (2015): Red book of threatened fishes of Bangladesh: IUCN-The World Conservation Union. Bangladesh Country Office, Dhaka, Bangladesh, 360pp.

Khanom, D. A., Khatun, T., Jewel, M. A. S., Hossain, M. D., Rahman, M. M. (2016): Present status of fish biodiversity and abundance in Shiba river, Bangladesh. University Journal of Zoology, Rajshahi University, 35, 7-15.

Magurran, A. E. (1988): Ecological diversity and its 
measurement, Princeton Princeton University Press. 7-45pp.

Majumdar, B. C. (2017): Comparison of the changes in nutritional quality of three important small indigenous fish species in Bangladesh at room temperature (27-31 $\left.{ }^{\circ} \mathrm{C}\right)$ : A review. Journal of Animal Research and Nutrition, 2, 2, 15.

Majumdar, B. C., Paul, S. I., Hasan, M., Kabir, T., Islam, M., Kabir, I. E. (2020) Fish Biodiversity Assemblages and Fishing Gears Used at Chinadi Beel in Narsingdi District of Bangladesh. International Journal of Agriculture, Environment and Biotechnology , 13, 4, 403-413.

Majumdar, B. C., Rashid, I. (2017): Microbiological properties of dry salted Hilsa, Tenualosa ilisha (Hamilton, 1822) fish of Bangladesh. Journal of Fisheries and Life Sciences, 2, 2, 4-9.

Majumdar, B. C., Shaha, D. C., Rasul, M. G., Khan, M. (2016): Fish production in floodplain of Bangladesh: A review. International Journal Natural Sciences, 6, 2, 89-95.

Margalef, R. (1968): Perspectives in Ecological Theory, Chicago, IL.: University of Chicago press. 111pp.

Mohsin, A. B. M., Haque, S. M. M., Galib, S. M., Fahad, M. F. H., Chaki, N., Islam, M. N., Rahman, M. M. (2013): Seasonal abundance of fin fishes in the Padma River at Rajshahi district, Bangladesh. World Journal of Fish and Marine Sciences, 5, 6, 680-685.

Moniruzzaman, M., Elahi, S., Jahangir, M. (2009). Study on Temporal Variation of Physico-chemical Parameters of Buriganga River Water through GIS (Geographical Information System) Technology. Bangladesh Journal of Scientific and Industrial Research, 44, 3, 327-334.

Nabi, G., Amin, M., Ullah, N., Ahmed, N. (2014). An over view on the causes, types and role of hormones in fish migration. International Journal of Scientific \& Engineering Research, 5, 8, 404-412.

Nouri, J., Fatemi, M. R., Danekar, A., Fahimi, F. G., Karimi, D. (2009). Determination of environmentally sensitive zones along Persian Gulf coastlines through geographic information system. Journal of Food, Agriculture \& Environment, 7, 2, 718-725.

Pielou, E. C. (1966): Species-diversity and patterndiversity in the study of ecological succession. Journal of Theoretical Biology, 10, 2, 370-383.

Rahman, A. K. A. (1989): Freshwater Fishes of Bangladesh. University of Dhaka, Dhaka, Bangladesh. 234 pp.

Rahman, A. K. A. (2005): Freshwater Fishes of Bangladesh (second edition), Zoological Society of Bangladesh: University of Dhaka, Dhaka, Bangladesh. 263pp.

Rahman, M. A., Mondal, M. N., Hannan, M. A., Habib, K. A. (2015): Present status of fish biodiversity in Talma River at northern part of Bangladesh. International Journal of Fisheries Aquatic Studies, 3, 1, 341-348.
Rahman, M. M., Hossain, M. Y., Ahamed, F., Fatematuzzhura, S. B. R., Abdallah, E. M., Ohtomi, J. (2012): Biodiversity in the Padma distributary of the Ganges River, northwestern Bangladesh: recommendations for conservation. World Journal of Zoology, 7, 4, 328-337.

Rahman, M. R. (2015): Causes of biodiversity depletion in Bangladesh and their consequences on ecosystem services. American Journal of Environmental Protection, 4, 5, 214-236.

Saha, B. K., Hossain, M. A. (2002): Saldu beel fishery of Tangail. Bangladesh Journal of Zoology, 30, 2, 187-194.

Sarker, M.A.K. 2005. Study on the accumulation and seasonal variation of trace metals in water, Sediment and some fishes of the Buruganga river. Department of Zoology, Dhaka University. pp. 1-4.

Shahjahan, M., Miah, M. I., Haque, M. M. (2001): Present status of fisheries in the Jamuna river. Pakistan Journal of Biological Scienes, 4, 9, 1173-1176.

Shannon, C. E., Weaver, W. (1963): The Mathematical Theory of Communications, Urbana, IL: University of Illinois Press. 125pp.

Sheikh, A. H., Mondal, A. R., Majumdar, B. C., Rayhan, A., Hossen, M. N. (2018): Spawning and mortality of eggs and larvae produced by different brood sizes of Walking Catfish (Clarias batrachus L.). Journal of Applied and Advanced Research, 3, 3, 78-83.

Shovon, M. N. H., Majumdar, B. C., Rahman, Z. (2017): Heavy metals (lead, cadmium and nickel) concentration in different organs of three commonly consumed fishes in Bangladesh. Fisheries and Aquaculture Journal, 8, 3, 207.

Suravi, I. N., Islam, M. S., Begum, N., Kasem, M. A. (2017): Fish bio-diversity and livelihood of fishers of Dekar haor in Sunamganj of Bangladesh. Journal of Asiatic Society of Bangladesh, Science, 43, 2, 233-244.

Talwar, P. K., Jhingran, A. G. (1991): Inland Fishes of India and Adjacent Countries, New Delhi, India: IBH publishing Co. Pvt. Ltd.

Uddin, M. N., Alam, M. S., Mobin, M. N., Miah, M. A. (2014). An assessment of the river water quality parameters: $A$ case of Jamuna River. Journal of Environmental Science and Natural Resources, 7, 1, 249-256.

Vyas, V., Damde, D., Parashar, V. (2012): Fish biodiversity of Betwa River in Madhya Pradesh, India with special reference to a sacred ghat. International Journal of Biodiversity and Conservation, 4, 2, 71-77.

Winemiller, K. O. (1989). Patterns of variation in life history among South American fishes in seasonal environments. Oecologia, 81, 2, 225-241.

Zafar, M. S., Amin, M. N., Iqbal, M. J. (2007): Biodiversity of fisheries organisms in the Pagla river of Bangladesh. Bangladesh Journal of Fisheries, 30, 165-175. 
Croatian Journal of Fisheries, 2021, 79, 173-186

S. I. Paul et al. (2021): Biodiversity of fish fauna in the Jamuna River

Zaman, M., Naser, M. N. (2019): Fish species using the fish passage between Jamuna and Bangali river at Sariakandi, Bogra. Journal of Biodiversity Conservation and Bioresource Management, 5, 2, 53-62. 